يزوهشهاى زنتيك گياهى / جلد / / شماره |

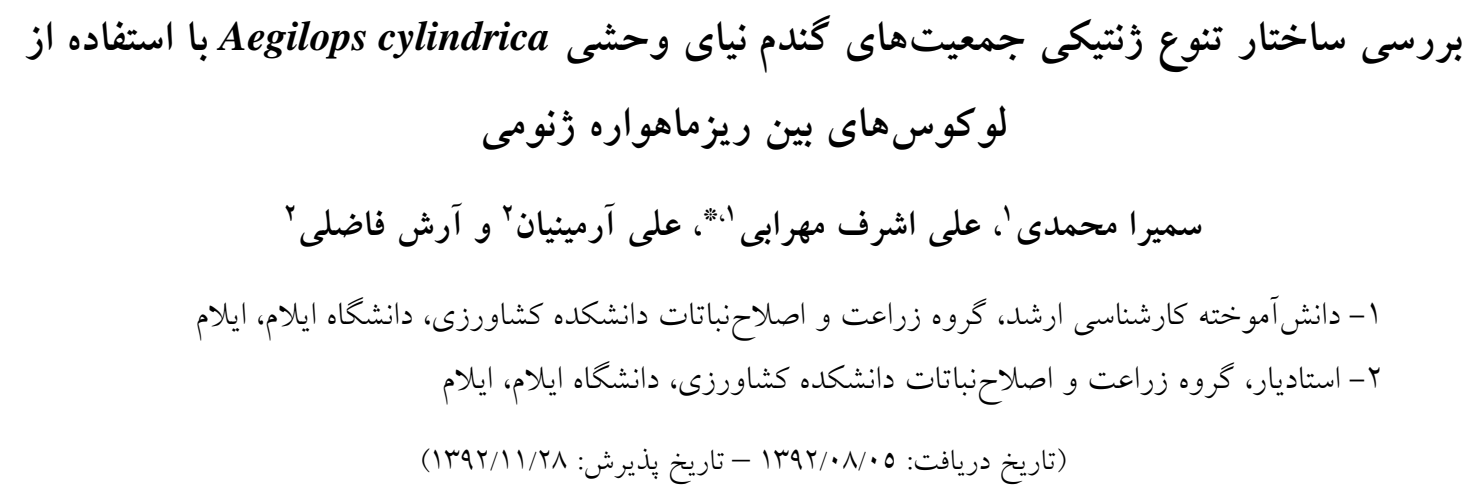

به منظور بررسى تنوع زنتيكى Oب جمعيت Aegilops cylindrica با استفاده از V آغازكر ISSR، در مجموع •19 آلل تكثير

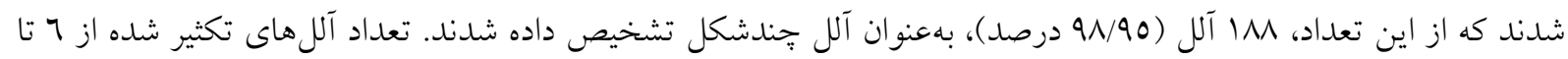

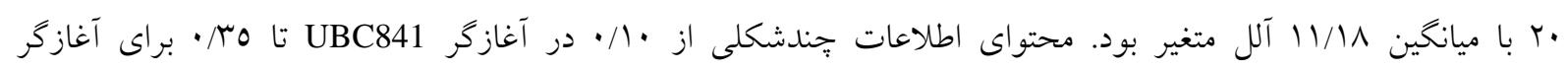

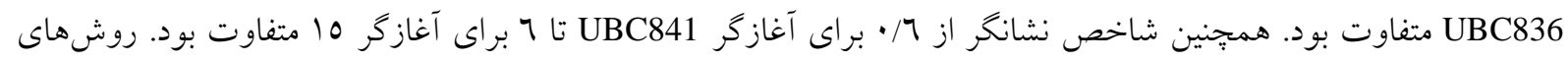

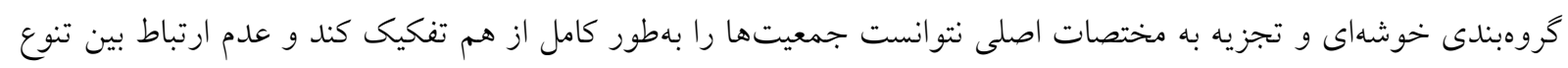

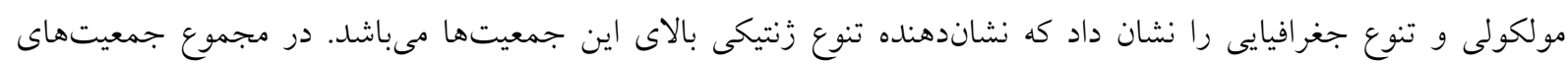

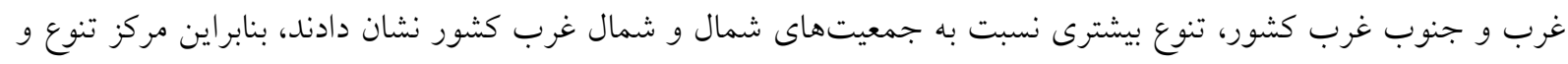

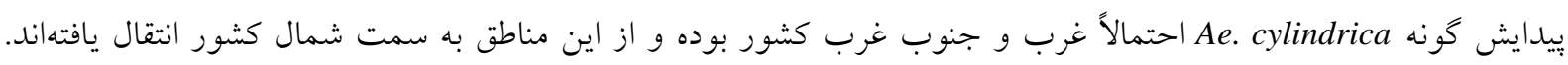

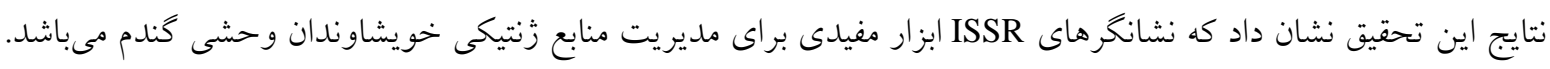
وازگكان كليدى: Aegilops cylindrica تجزيه به مختصات اصلى، تجزيه خوشهاى، تنوع زنتيكى، نشانگر ISSR 
موجود و قابل تكثير بين دو ريز ماهواره را كه در جهت

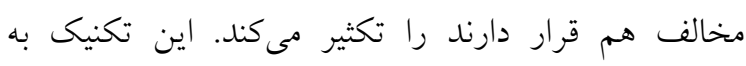

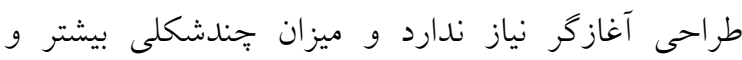
آشكارسازى راحتترى نسبت به ديخر نشانخرهاى مولكولى دارد (Terzopoulos and Bebeli, 2008). اين نشانخرها در مطالعات تنوع زنتيكى، فيلوزنى'، نشاندار كردن' زنى، نقشهيابى زنومى و زيستشناسى تكاملى به كار مىروند (Reddy et al., 2002). جم باراندوزى و همكاران (Jam Baranduzi et al., 2013) براى بررسى تنوع زنتيكى

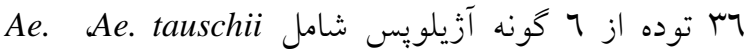
Ae. Ae. triuncialis Ae. umbellulata ‘cylindrica IS Ae.crassa giuncialis كردند، در نهايت آIVI باند تكثير شد كه IVI باند از آنها جندشكل بودند. فرخارى و همكاران ( Farkhari et al., 2007) با مطالعه تنوع زنتيكى بر جمعيت Ae. cylindrica ايران با استفاده از عا آغازگر RAPD دريافتند كه ارتباطى بين تنوع زنتيكى و منشأ جغرافيايى آنها وجود ندارد. مرادخانى و همكاران (Moradkhani et al., 2012)، نيز با ارزيابى تنوع زنتيكى •ب زنوتيب از ه كونه كندم زراعى و Ae. Ae. crassa Ae. cylindrica A. tauschii Triticum aestivum و با •ا آغازگر speltoides سطح بالايى از تنوع زنتيكى را در درون كونهها مشاهده كردند. نقوى و همكاران (Naghavi et al., 2009)، جفت آغازگر ريزماهواره را براى بررسى روابط زنتيكى بين Ae. cylindrica Ae. tauschii نمونه از جهار كونه Ae. crassa

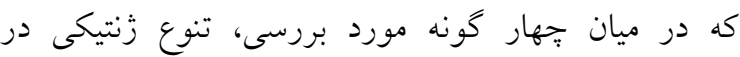
كونهاى Ae. cylindrica و T. aestivum بسيار كمتر بود.

بهطوركلى اهداف اصلى اين تحقيق عبارت بودند از:

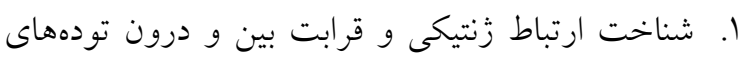
Ae. cylindrica

1. Phylogeny

2. Tagging

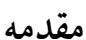

كونه Aegilops cylindrica Host، كياهى يكساله، خودگشن و متعلق به خانو اده Poaceae و طايفه Triticeae

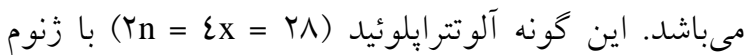
Ae. است كه با دورگ گيرى بين گونهاى دييلوئيد CCDD

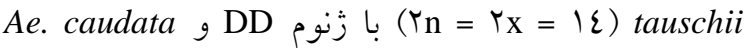

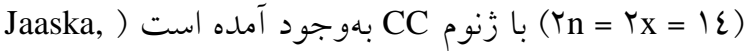
1981; Johnson, 1976 مركز تنوع اين گونه در هلال حاصلخيز و آسياى مركزى بوده و در بيشتر نواحى ايران يافت مى گردد (Van Slageren, 1994). اين گونه به دلايل مختلفى در سراسر جهان اهميت اقتصادى دارد، از جمله اينكه يك علف هرز شايع در مزارع كندم نان است و بهطور وسيعى در مزارع ايالات متحده آمريكا، خاورميانه و Gandhi et al., ) بخشهايى از ارويا كسترش مىيابد

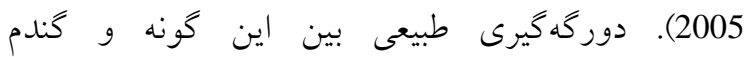
نشاندهنده يُانسيل براى جريان زن بين اين گونه و گُندم Gandhi et al., 2009; ) تحت شرايط مزرعه مىباشد Gandhi et al., 2005 Farooq et al., ( منبع از صفات مفيد مانند تحمل به شورى 1992)، مقاومت به مخس كَندم ( El Bouhssini et al., 1998) و متحمل به سرما (Iriki et al., 2001) شناخته شده است. براى اصلاح كُندم بررسى تنوع زنتيكى در

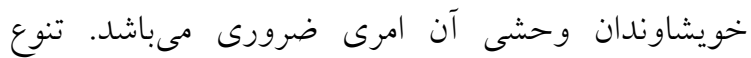
زنتيكى در كونه Ae. cylindrica با استفاده از نشانخرهاى Farkhari et al., 2007; Goryunova et al., ) RAPD 2004)، تركيب نشانگرهاى RAPD و Pester et ) AFLP al., 2003 ، نشانكرهاى ريزماهواره كلرويلاست و هستهاى Watanabe et (Gandhi et al., 2009) Khabiri et al., ) و يروتئينهاى ذخيرهاى (al., 1994 (2013; Khabiri et al., 2012 است. يكى از نشانكرهايى كه در مطالعات تنوع زنتيكى موجودات زنده و كياهان كاربرد دارد، نشانگر ISSR است، نشانكرى مبتنى بر PCR است كه قطعه ISSR 


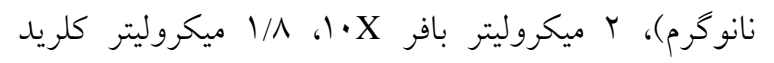

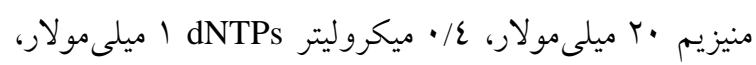

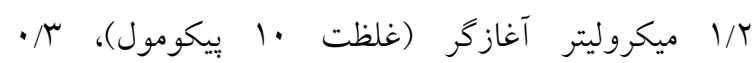

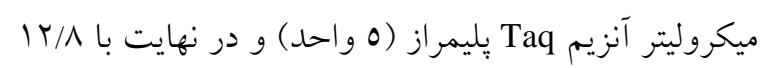

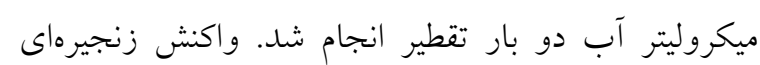

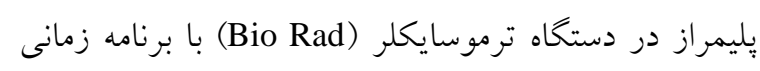
ع دقيقه واسرشتسازى اوليه در دماى عq درجه سانتيكراد، • إخرخه اوليه بهصورت Touchdown (بهطورى كه دماى اتصال آغازكر به رشته الكو 0 درجه سانتى كراد بالاتر از بهوريه

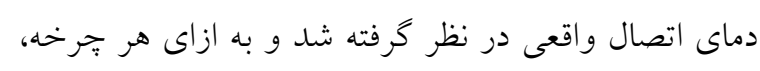

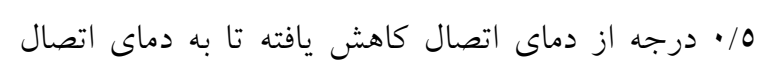

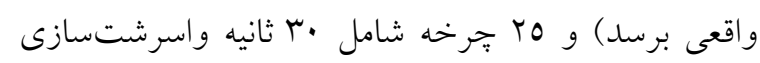

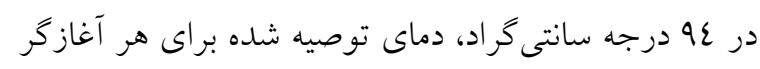

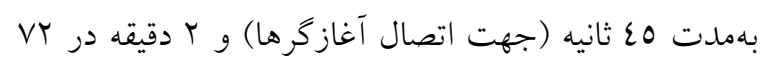

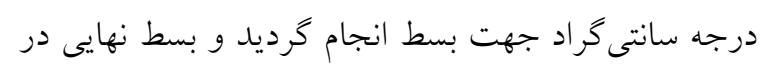

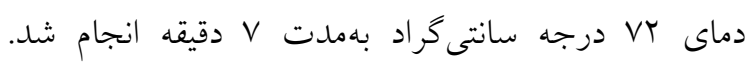
قطعات DNA تكثير شده با استفاده از الكتروفورز زل

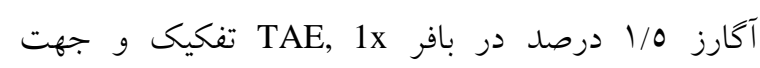

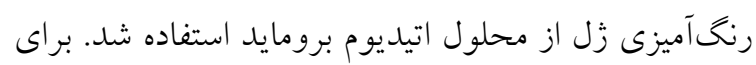

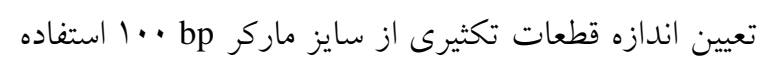

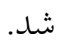

تجزيه و تحليل دادهها: باندهاى حاصل از تكثير جمعيتها با استفاده از هر آغازكر بهعنوان دادههاى اوليه با داديا اعداد يكى (براى وجود باند) و صفر (براى عدم وجود باند)

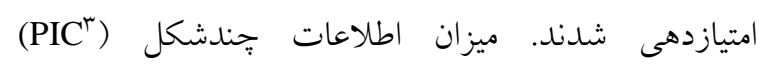
فرمول PIC = محاسبه كرديد كه در آن Pij

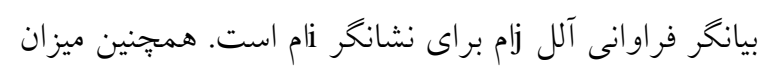
MI = شاخص نشانكر (MI') با استفاده از فرمول Powell et al., 1996; Anderson ) محاسبه شد PIC ميـانخيــن ميـزان Paـ al., 1993

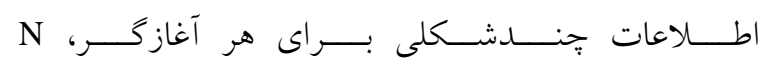

3. Polymorphic Information Content 4. Marker Index
بر اساس انگشتنگارى زنومى حاصل از نشانگرهاى

ISSR

r. مطالعه ميزان تنوع و تفرق زنتيكى جمعيتهاى

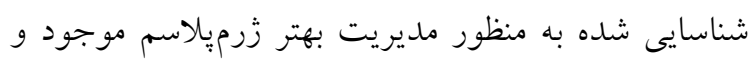

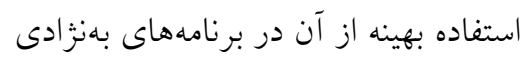

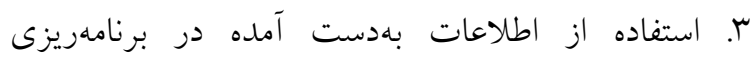
Ae. حفاظت زرميلاسم و ايجاد كلكسيون از جمعيتهاى جهت كارهاى اصلاحى cylindrica

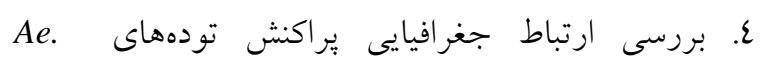
cylindrica

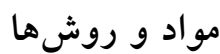

Ae. cylindrica مواد گياهى: در اين تحقيق از مب جمعيت استفاده شد كه از 11 استان شامل كيلان، اردبيل، آذربايجان

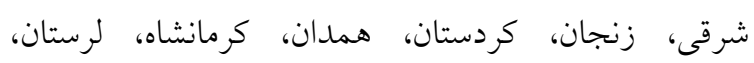

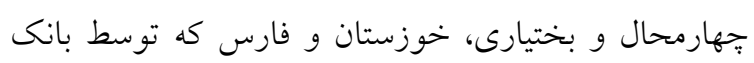
زن غلات و حبوبات غرب كشور واقع در دانشكده

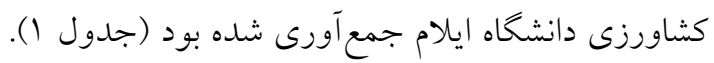
استخراج DNA زنومى: DNA زنومى بهصورت بالك از بافت برى گياهجههاى دو تا سه بركى رشد يافته در گلدان

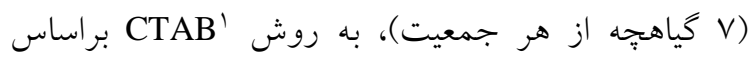

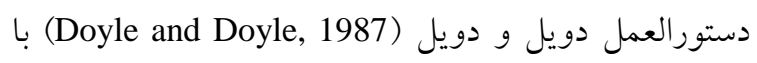
اندكى تغييرات استخراج كرديد. كميت و كيفيت DNA

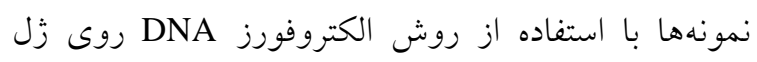

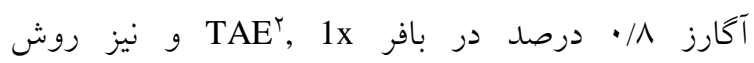

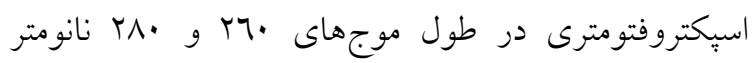

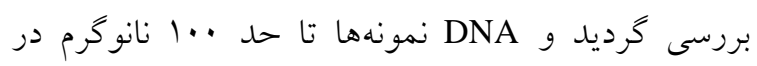
ميكروليتر رقيق شد. مراحل واكنش زنجيرهاى يُليمراز: براى انجام واكنش

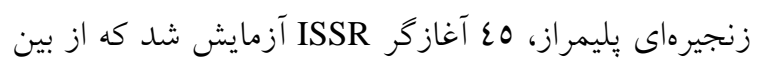

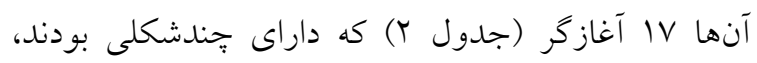

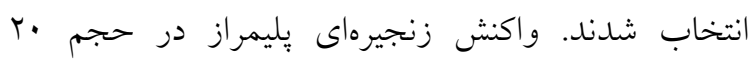

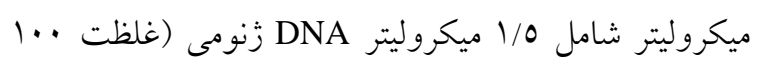

1. Cethyl Trimethyl Ammonium Bromide

2. Tris Acetate EDTA 
جدول ا- جمعيتهاى Aegilops cylindrica مورد استفاده در اين تحقيق

Tab 1. List of Aegilops cylindrica populations used in this study

\begin{tabular}{|c|c|c|c|c|c|c|c|}
\hline مديف & كد & Collection sites & محل جمع آورى & ريف & كد Code & Collection sites & محل جمع آورى \\
\hline 1 & $\mathrm{AC} 1$ & - & - & 19 & AC19 & Lorestan-Nourabad & لرستان- نورآباد-روستاى ده \\
\hline 2 & $\mathrm{AC} 2$ & - & - & 20 & $\mathrm{AC} 20$ & - & - \\
\hline 3 & AC3 & Ardebil-sareyn & جاده اردبيل - سرعين - 10 & 21 & $\mathrm{AC} 21$ & - & - \\
\hline 4 & $\mathrm{AC} 4$ & Kurdestan-Sanandaj & كردستان- • ب كيلومترى & 22 & $\mathrm{AC} 22$ & Kermanshah-Javanroud & 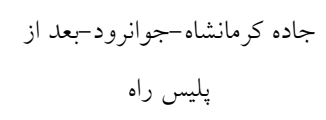 \\
\hline 5 & AC5 & Iran-Unknow & $\begin{array}{c}\text { ايران (محل جمع آورى } \\
\text { ناشناخته) }\end{array}$ & 23 & $\mathrm{AC} 23$ & - & - \\
\hline 6 & AC6 & Khuzestan-Izeh & خوزستان- ناغان - ايذه & 24 & $\mathrm{AC} 24$ & Kermanshah-Harsin & 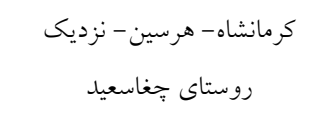 \\
\hline 7 & AC7 & Azarbayejan-Kaleybar & أذربايجان شرقى - آكيلومترى اهر - كليبر . & 25 & AC25 & Azarbayejan-Kaleybar & آذربايجان شرقى - • اكيلومترى \\
\hline 8 & AC8 & Lorestan-Sepiddasht & 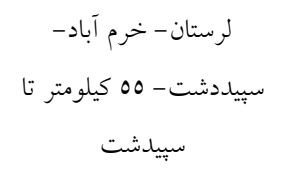 & 26 & AC26 & Hamedan-Hamedan & همدان - جاده اسدآباد - همدان \\
\hline 9 & AC9 & Tehran-Tehran & ورودى جاده زنجان -تهران & 27 & $\mathrm{AC} 27$ & Guilan-Astara & كيلان- آستارا- روستاى حيران \\
\hline 10 & $\mathrm{AC} 10$ & Kurdestan-Saghez & كردستان- بعد از زرينه به & 28 & $\mathrm{AC} 28$ & $\begin{array}{c}\text { Chaharmahale Bakhtiari- } \\
\text { Shahrekord }\end{array}$ & جهارمحال و بختيارى- حومه \\
\hline 11 & $\mathrm{AC} 11$ & Lorestan-Dorud & لرستان- جاده اليخودرز - لرورد- مع تا دورود & 29 & AC29 & Kermanshah-Harsin & كرمانشاه - هر سين \\
\hline 12 & $\mathrm{AC} 12$ & Azarbayejan-Miandoab & آذربايجان شرقى - جاده & 30 & AC30 & Lorestan-Sepiddasht & لرستان- · ب كيلومترى خرم آباد- \\
\hline 13 & $\mathrm{AC} 13$ & Azarbayejan-Tabriz & 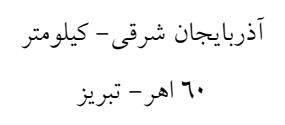 & 31 & $\mathrm{AC} 31$ & Kermanshah-Songhor & كرمانشاه- سنقر - اسد آباد- \\
\hline 14 & $\mathrm{AC} 14$ & $\begin{array}{l}\text { Kermanshah- } \\
\text { Kermanshah }\end{array}$ & كرمانشاه - جاده هرسين - & 32 & $\mathrm{AC} 32$ & Tehran-Tehran & ورودى جاده زنجان - تهران \\
\hline 15 & $\mathrm{AC} 15$ & Fars-Shiraz & فارس - بردج شيراز & 33 & $\mathrm{AC} 33$ & Azarbayejan-Bonab & آذربايجان شرقى - جاده آذر \\
\hline 16 & AC16 & Kurdestan-Kamyaran & كردستان- ك كيلومترى & 34 & $\mathrm{AC} 34$ & Lorestan-Sepiddasht & سبيدوشت سرنان- جاده خرم آباد- \\
\hline 17 & $\mathrm{AC} 17$ & Lorestan-Veysian & جاده خرم آباد- انديمشك - -روستاى ويسيان & 35 & AC35 & Guilan-Astara & كَيلان - جاده صومعه سر ا- آستارا \\
\hline 18 & AC18 & Kermanshah-Javanrud & كرمانشاه- دوراهى جوانرود & & & & \\
\hline
\end{tabular}

نمونه هاى شماره مرو عَ از لحاظ موروفوتيب و رنگ خوشه كاملاً از هم متمايز بودند.

The samples No. 8 and 34 are entirely different with respect to morphotype and spike color. 
همكاران (Farkhari et al., 2007) با استفاده از عا آغازكر RAPD، درصد جֶندشكلى 79 درصد گزارش شد. تعداد آللها در تحقيق حاضر، از 7 تا •r متغير بود و ميانخين آللهاى توليد شده، 11/11 براى هر آغازكر بود. در بين

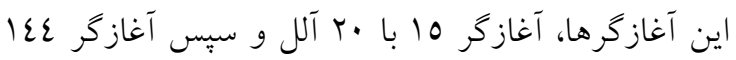
با ها آلل، بيشترين آلل رادر ميان آللهاى توليدى توسط هر آغازكر داشتند. آغازگر UBC823 نيز با 7 آلل كمترين تعداد آلل را به خود اختصاص داد (جدول Y). نجفى و همكاران (Najaphy et al., 2011) نيز در بررسى تنوع زنتيكى زنوتيِهاى گندم تعداد آللها را ه تا •r و

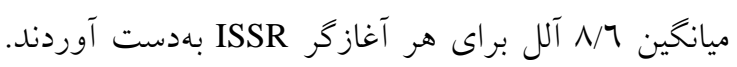
محدوده قطعات توليد شده در تحقيق حاضر، از ب. جفت باز (آغازگر UBC836) تا ..010 جفت باز (آغازگر

$$
\text { (UBC815) متغير بود (جدول Y). }
$$

محاسبه محتواى اطلاعات جندشكلى و شاخص نشانگر: محتواى اطلاعات جنندشكلى و شاخص نشانگر هر آغازگر، به طور جداگانه محاسبه گرديد كه نتايج درجدول r آمده است. آغازگر UBC836 بيشترين ميزان

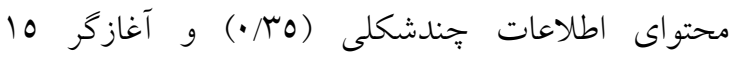
بيشترين شاخص نشانكر (7) را نشان دادند. كمترين ميزان محتواى اطلاعات پجندشكلى (•/(•) و شاخص نشانكر (7/ •) براى آغازگر UBC841 بهدست آمد. ميانخين محتواى اطلاعات جندشكلى (r//·) و ميانخين شاخص نشانكر (Y/VI) محاسبه شد. توماس و ببلى (Thomas نيز در بررسى تنوع زنتيكى كونههاى (and Bebeli, 2010 آزيلويس ميانخين محتواى اطلاعات جندشكلى را ب / • و

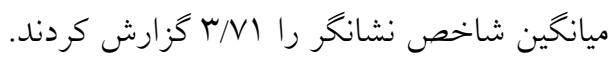

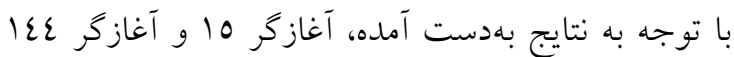
با داشتن بيشترين شاخص نشانكر، قدرت تفكيك بالاترى در مقايسه با ساير آغازگرها دارند، بنابراين
تعدادكل باندها براى هر آغازگر و م نسبت جنندشكلى براى هر آغازگر مىباشد. شاخص MI علاوهبر مزاياى شاخص PIC، تعداد كل نوار و نسبت هندشكلى را نيز در نظر كرفته و يتانسيل هر آغازكر را جهت توليد آلل بيشتر نشان مى دهد. شاخصهاى عدم تشابه همر اه با روشهاى اتصال ميانگين (UPGMA') و اتصال مجاور (NJ') با Perrier and ) DARwin 5.0 استفاده از نرم|فزار، محاسبه و با استفاده از (Jacquemoud-Collet, 2006 نرمافزار XLSTAT مقايسه شدند. با روش تجريه به مختصات اصلى (PCoA ${ }^{r}$ ) با استفاده از نرمافزار Dرومبندى جمعيتها در يك نمودار سه 5.0 Barbara et ) Minitab بعدى ترسيم شده با نرمافزار 16 (al., 2012 GenALEx 6.41 اصلى گروهها نيز با استفاده از نرمافزار محاسبه گرديد و نمودار (Peakall and Smouse, 2006) سه بعدى گروهها با نرمافزار Minitab 16 ترسيم شد. از نرمافزار Kumar et al., 2004) MEGA 3.1 براى تجزيه خوشهاى و محاسبه فاصله زنتيكى درون جمعيتها GenALEx استفاده كرديد و ستر با استفاده از نرمافزار 6.41، فاصله زنتيكى بين جمعيتها، درصد آللهاى جندشكل، شاخص تصحيح شده هتروزنى و شاخص اطلاعات شانون محاسبه و تجزيه واريانس مولكولى نيز

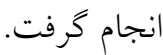

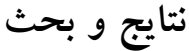
محاسبه جֶندشكلى: با استفاده از V آغازگر بهكار رفته در

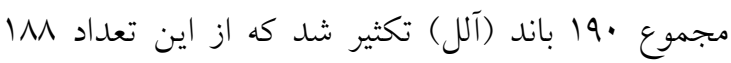
آلل، بهعبارت ديخر 9/90 درصد آللها بهعنوان آلل جندشكل تشخيص داده شدند. در مطالعه فرخارى و

1. Unweighted Paired Group Method using Arithmetic average

3. Principal Coordinates Analysis 
آذربايجان شرقى، كردستان، لرستان، زنجان، اردبيل،

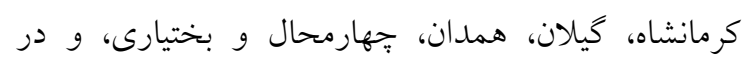
كروه دوم نيز ع جمعيت از استانهاى كردستان، فارس،

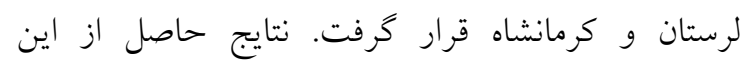
دندروكرام، عدم ارتباط بين تنوع مولكولى و تنوع

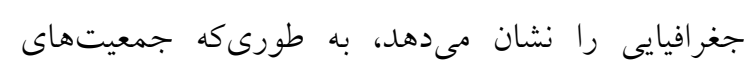

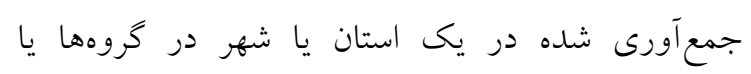

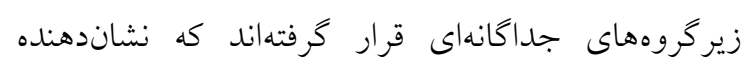

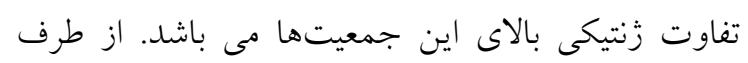

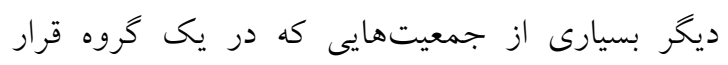
كرفتهاند از مناطق جغرافيايى متفاوت هستند كه اين مورد

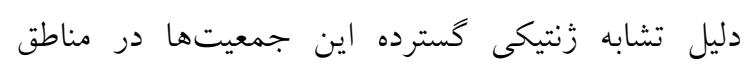
مختلف كشور مى باشد. اين نتايج با مطالعات ديخر

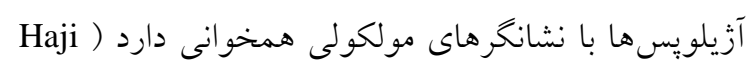

Karam et al., 2011; Ranjbar et al., 2008; Farkhari et .al., 2007

در تحقيق حاضر، جمعيت ناشناخته با كد AC0 با جمعيت AC7 (ناغان-ايذه) در يك خوشه قرار كرفتهاند،

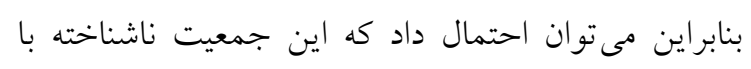
كد ACO به جمعيت AC7 نزديك است. جمعيتهاى ناشناخته با كدهاى ACl و ACr با جمعيت

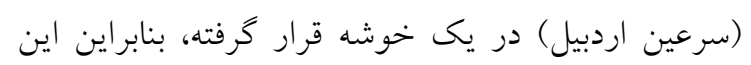
جمعيت ها به هم نزديك هستند. جمعيت هاى ناشناخته با رديا

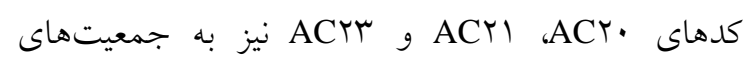
ACYY ACl9 تجزيه به مختصات اصلم جمعيتها: اطلاعات حاصل از

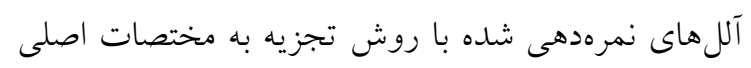
(PCoA) نتايج حاصل از تجزيه به مختصات اصلى نشان مى دهد كه

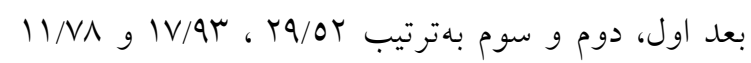

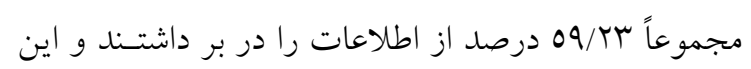

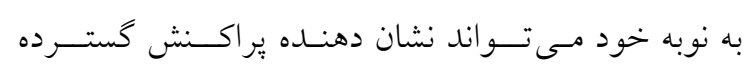

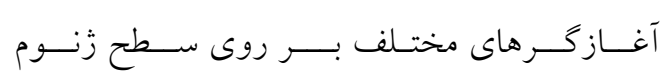

مىتوان استفاده از اين آغازگرها را براى بررسى تنوع

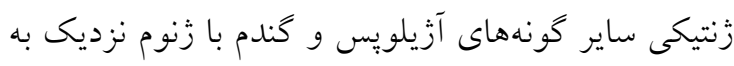
Ae. cylindrica محاسبه ضرايب همبستكى كوفنتيك: در اين تحقيق براى مشخص كردن بهترين شاخص عدم تشابه و تشخيص

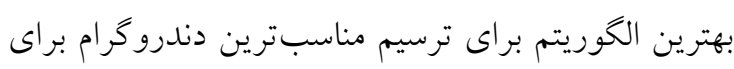

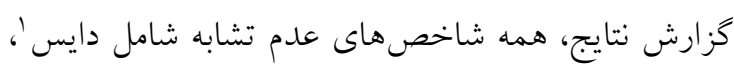

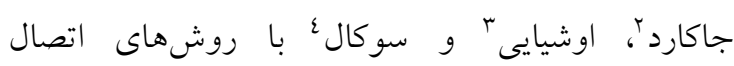

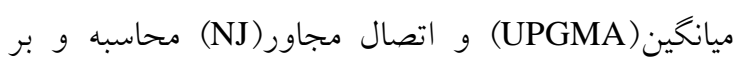

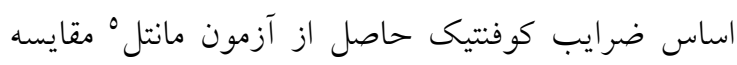

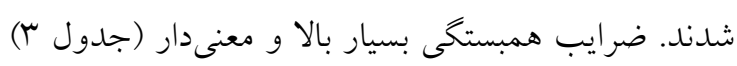
نشاندهنده تطابق ماتريسهاى بهدست آمده از اين جهار شاخص است. از اين رو بههنگام استفاده از تعداد زياد

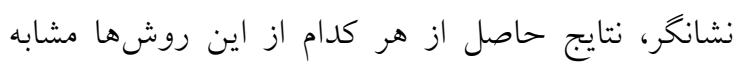

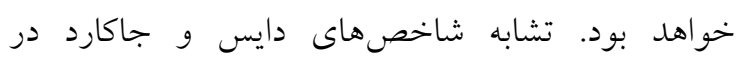
مطالعات بررسى تنوع زنتيكى گُندمهاى وحشى قبلاً نيز

كزارش شده است (Kharestani, 2010; Shiri, 2009). بهدليل كزارشات متعدد و عموميت بيشتر شاخص دايس، از اين شاخص در محاسبه فواصل زنتيكى بين و درون

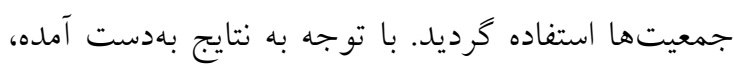

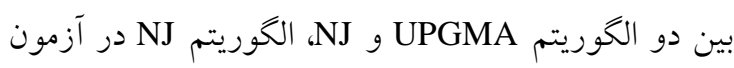
مانتل ضريب كوفنتيك بالاترى نشان داد، در نتيجه در كزارش نتايج از اين روش استفاده شد.

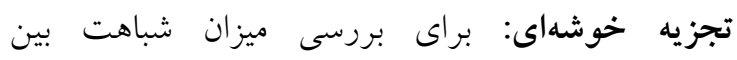
جمعيتهاى مختلف و كروهبندى آنها، با استفاده از دادههاى حاصل از ماتريس عدم تشابه دايس و الكوريتم

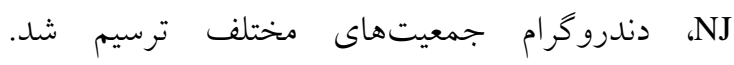

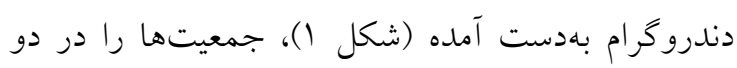
كروه عمده و زيركروههاى متعددى قرار داد. بهطورىكه

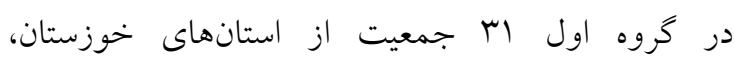


يُوهشهاى زنتيك گياهى / جلد / / شماره |

جدول - مشخصات آغاز كرهاى مورد استفاده بههمراه محتوى اطلاعات جندشكلى و شاخص نشانكر آنها

Table 2. Primer characteristics used in this study, polymorphic information contents and marker index

\begin{tabular}{|c|c|c|c|c|c|c|c|c|}
\hline $\begin{array}{c}\text { اندازه قطعات تكثيرى (جفت باز) } \\
\text { Amplified fragment length } \\
\text { (bp) }\end{array}$ & MI & PIC & $\begin{array}{l}\text { درصد جندشكلى } \\
\text { Percentage of } \\
\text { polymorphism }\end{array}$ & $\begin{array}{c}\text { جندشكلى تعداد آلرهاى } \\
\text { No. } \\
\text { Allelepolymorphic } \\
\text { alleles }\end{array}$ & $\begin{array}{c}\text { تعداد آللها } \\
\text { Allele } \\
\text { No. }\end{array}$ & $\begin{array}{c}\text { دماى اتصال } \\
\left({ }^{\circ} \mathrm{C}\right) \\
\text { Annealing } \\
\text { Tm }\left({ }^{\circ} \mathrm{C}\right)\end{array}$ & $\begin{array}{c}\text { توالى آغازكر } \\
5^{\prime} \rightarrow 3^{\prime} \\
\text { Primer } \\
\text { sequence }\end{array}$ & $\begin{array}{c}\text { نام آغازگر } \\
\text { Primer } \\
\text { name }\end{array}$ \\
\hline $330-800$ & 1.5 & 0.2 & 100 & 7 & 7 & 50 & $(\mathrm{GA}) 8 \mathrm{~A}$ & UBC812 \\
\hline $350-2500$ & 2.2 & 0.3 & 100 & 7 & 7 & 52 & (CT) $8 \mathrm{G}$ & UBC815 \\
\hline $400-900$ & 0.7 & 0.1 & 100 & 6 & 6 & 52 & (TC) $8 \mathrm{C}$ & UBC 823 \\
\hline $200-980$ & 4.9 & 0.4 & 100 & 14 & 14 & 53 & (AG)7ACYA & UBC836 \\
\hline $350-1300$ & 2.8 & 0.2 & 100 & 12 & 12 & 53 & (GA)8YT & UBC 840 \\
\hline $250-1000$ & 0.6 & 0.1 & 85.7 & 6 & 7 & 55 & $(\mathrm{GA}) 8 \mathrm{YC}$ & UBC841 \\
\hline $200-900$ & 3.2 & 0.3 & 100 & 12 & 12 & 55 & $(\mathrm{GA}) 8 \mathrm{YG}$ & UBC842 \\
\hline $320-2000$ & 2.9 & 0.2 & 100 & 12 & 12 & 53 & (TC)8RT & UBC853 \\
\hline $600-1500$ & 1.8 & 0.2 & 100 & 10 & 10 & 52 & (AC) $8 \mathrm{C}$ & ISSR04 \\
\hline $280-1200$ & 1.4 & 0.1 & 91.7 & 11 & 12 & 50 & $(\mathrm{GA}) 8 \mathrm{~T}$ & ISSR08 \\
\hline $470-2000$ & 2.2 & 0.2 & 100 & 11 & 11 & 52 & (AC) $8 \mathrm{G}$ & ISSR10 \\
\hline $520-2000$ & 2.2 & 0.3 & 100 & 8 & 8 & 52 & (TCC)5 & ISSR15 \\
\hline $430-1300$ & 3.6 & 0.3 & 100 & 12 & 12 & 52 & (CA) $8 \mathrm{G}$ & ISSR17 \\
\hline $450-2000$ & 3.3 & 0.2 & 100 & 15 & 15 & 52 & (AC) $8 \mathrm{AT}$ & 12 \\
\hline $300-1700$ & 6 & 0.3 & 100 & 20 & 20 & 54 & (AC)8TG & 15 \\
\hline $330-800$ & 1.1 & 0.2 & 100 & 7 & 7 & 52 & (AG)8AA & 134 \\
\hline $300-2000$ & 5.6 & 0.3 & 100 & 18 & 18 & 54 & (AC) $8 \mathrm{G}$ & 144 \\
\hline
\end{tabular}

$\mathrm{Y}=(\mathrm{C} / \mathrm{T}), \mathrm{R}=(\mathrm{A} / \mathrm{G})$

$$
\text { جدول r- ضرايب همبستىى كوفنتيك }
$$

Table 3. Cophenetic correlation coefficients

الكوريتم ترسيم دندرو گرام (Clustering algorithms)

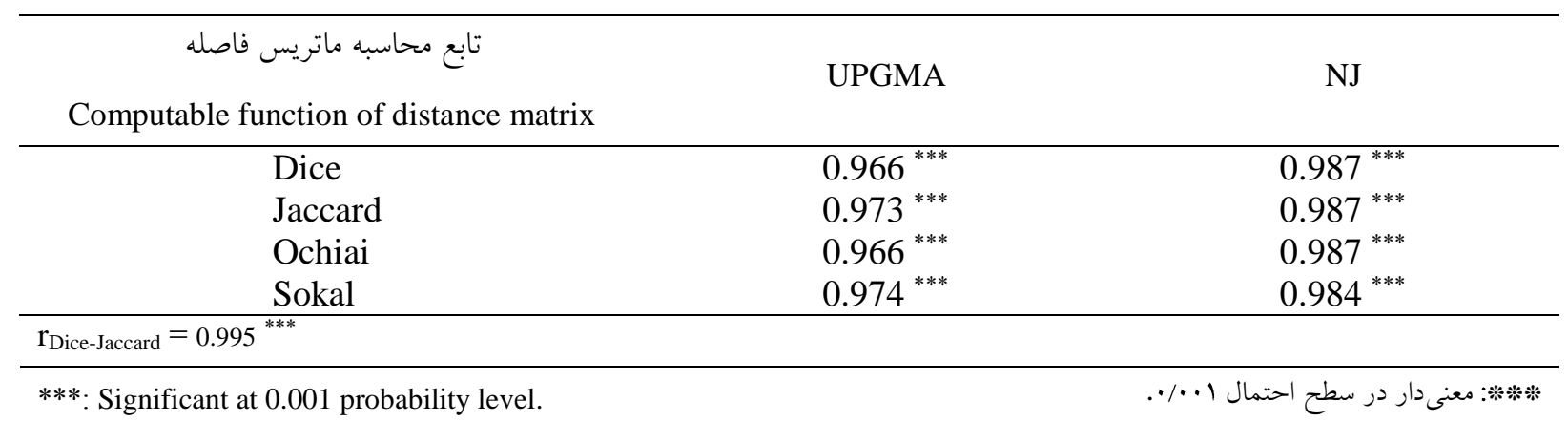




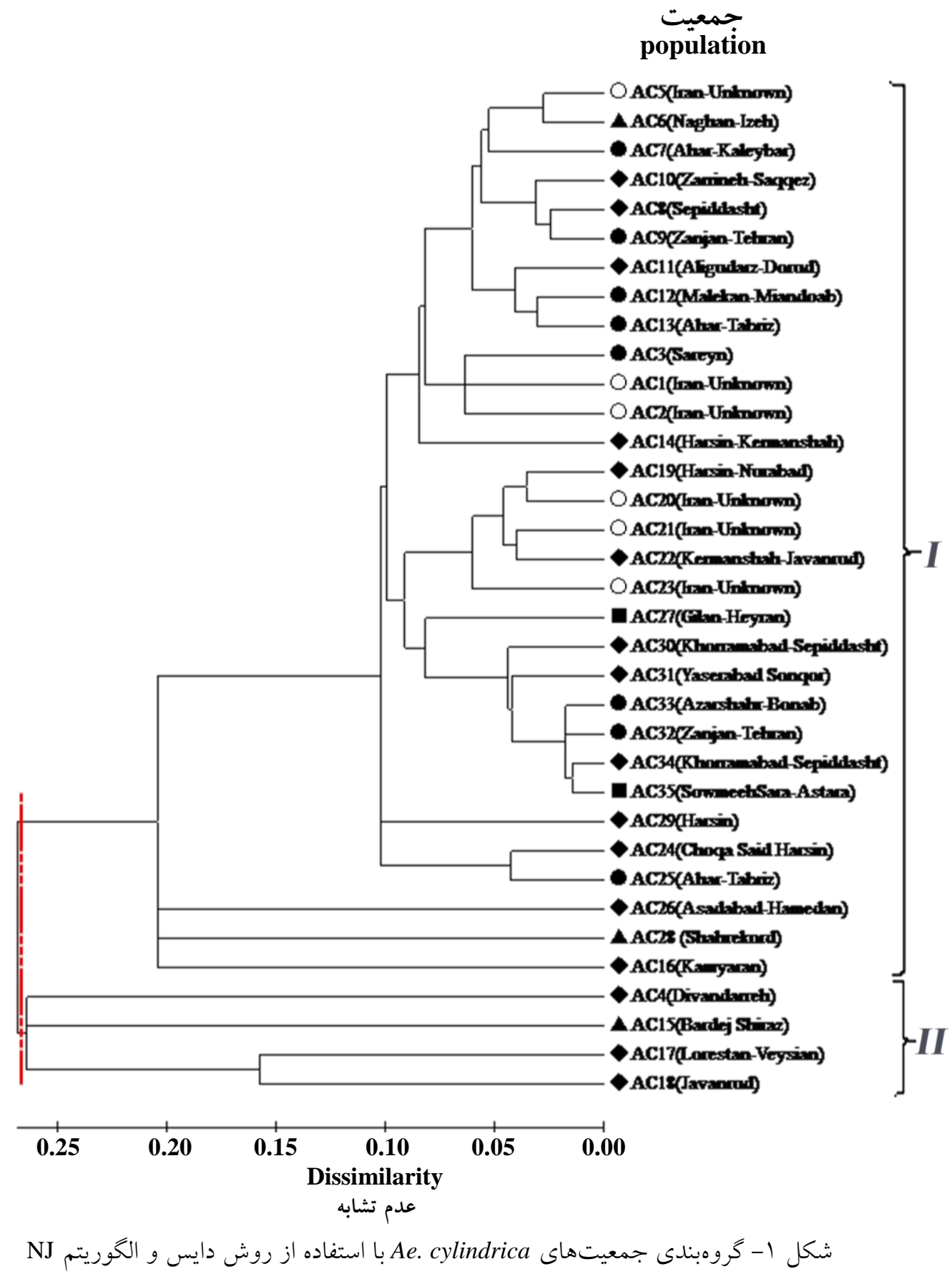

Figure 1. Grouping of Ae. cylindrica populations using Dice coefficient and NJ algorithm

كلى شمال با Y جمعيت، شمال غرب با 1 جمعيت، جنوب

غرب با ب جمعيت، غرب با 17 جمعيت و گروهى شامل 7

جمعيت با منشأ ناشناخته تقسيم شـدند. نتـايج حاصـل از

تجزيه به مختصـات اصسلى نشـان داد كسه بعــ اول، دوم و

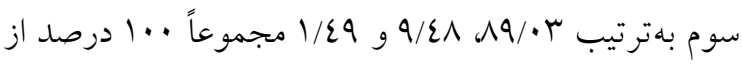

اطلاعات را در بر داشتند. بر اساس اين نمـودار (شـكل r)
Ae. cylindrica

حاصل از تجزيه به مختصات اصلى تا حدود زيادى با دندروكرام ترسيم شده (شكل (1)، همخوانى دارند. تجزيه به مختصات اصلى گروهها: به منظور بررسى بهتـر و دقيقتر اطلاعات مولكـولى نشـانكر ISSR، مورد بررسى براساس محل جمع آورى آنها به بــنج گـروه 
هتروزنى بيشـترى نشـان داد. كمتـرين درصــ آلـلهـاى

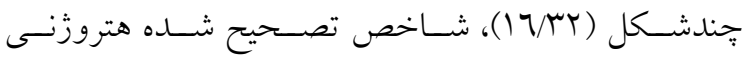
( • •/•) و شاخص شانون (99٪/•) نيز مربـوط بـه گــروه جمعيتهاى شمال كشور بود. تجزيه واريانس مولكولى: از آنجايى كه يكى از مهمتـرين جنبههاى تجزيه خوشـهاى، تعيسين تعـداد مطلـوب خوشـه است، به منظور تعيين تعداد مطلوب خوشه و تعيين بهترين

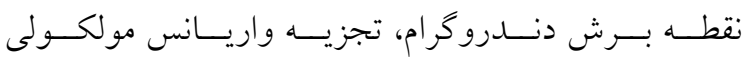
درون و بين گروهها صورت گرفت. در تجزيه (AMOVA) واريانس مولكـولى ايسن امكـان نيـز وجــود دارد تـا اجـزاء

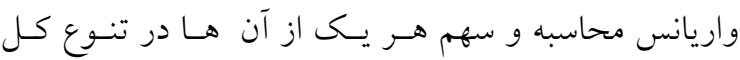
تعيين شود. نتـايج تجزيسه واريـانس مولكـولى (جـدول 7) نشان مى دهد كه اختلاف معنى دارى در سـطح آمـارى •1 بين ينج گروه وجود دارد كه طبق اين اطلاعات 90 درصــ از تنوع كل مربوط به تنوع درون گروهى و فقـط 0 درصــ آن مربوط به تنوع بين گروههاست. بهطوركلى جمعيتهاى غرب و جنوب غرب كشور تنوع بيشترى نسبت به جمعيتهاى شمال و شمال غرب كشور Ae. نشان دادند، بنابراين مركز تنوع و بيدايش كونه cylindrica اين كونه از اين مناطق به سمت شمال كشور انتقال يافتهاند. يكى از اهداف اوليه براى حفظ طبيعت، نخهداراى تنوع زنتيكى است. براى جمعيتهاى با سطوح بالاى تنوع زنتيكى در مناطق مختلف غرب و جنوب غرب كشور بيشنهاد مى گردد كه رويشخاه هاى آنها حفاظت شده و بهرهبردارى از منابع وحشى ممنوع كردد. جمعيتهاى شمال و شمال غرب كشور نيز بهتر است خارج از محل اصلى نخهدارى شوند و به برنامه دقيق و تهيه بانك

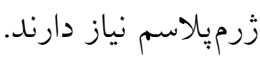

تنوع موجود در گروه جمعيتهاى ناشناخته به گروه شـامل

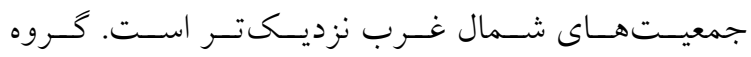
جمعيـتهـاى غـرب و جنـوب غـرب نسـبت بـه سـاير جمعيتها فاصله كمترى با مركز محور مختصات داشسته و اين نشاندهنده تنوع آللى و هتروزنى بالاى اين جمعيتهـا نسبت به ساير جمعيتها است. جمعيتهاى غرب و شمال غرب نزديكترين جمعيت ها به هم و دورترين جمعيـتهـا شمال و جنوب غرب هستند.

محاسبه فاصله زنتيكى درون و بين گروهها: براى آخـاهى از تنـوع زنتيكسى درون و بـين خـروههـاى مسورد بررسىى، فو اصل زنتيكى درون گروهها بر اساس ماتريس عدم تشـابه دايس و نيز ماتريس فاصله و تشابه بين خـروههـا از طريـق

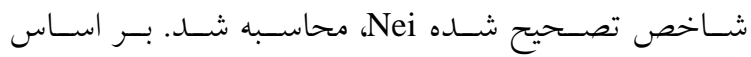
اطلاعات بهدست آمــه (جــدول ع) فاصـله زنتيكى درون

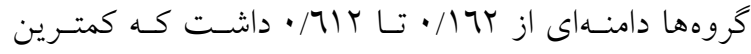

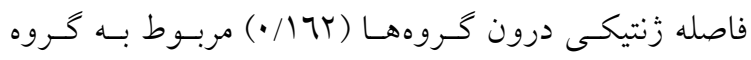

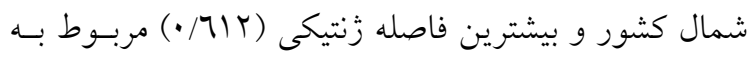
كروه جنوب غرب كشور مىباشد. بيشترين فاصله زننيكى شاخص Nei ميان دو كروه شمال و جنـوب غـرب كشـور (اب//•) و كم ترين فاصله نيز ميان گروه با منشأ ناشـناخته و خــروه شـمال غـرب كشـور (•r•/•) وجــود داشـت، بهعبارت ديخر اين دو كروه بيشترين شباهت زنتيكى را بـا

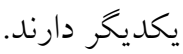

محاسبه شاخص هاى زنتيكى: ميزان آلـلهـاى جّندشـل، شـاخص تصـحيح شــه هتروزنس و شـاخص اطلاعـات شانون، براى هر كروه و ميانكين كـل آنهـا بـهدسـت آمـــ (جدول 0). كروه جمعيتهـاى غـرب كشـور بـا بـالاترين درصد آللهاى تندشكل (NM/EY)، شاخص تصحيح شـده هتروزنى (1/r9/•) و شاخص شانون (عrع/•) تنوع آللى و 


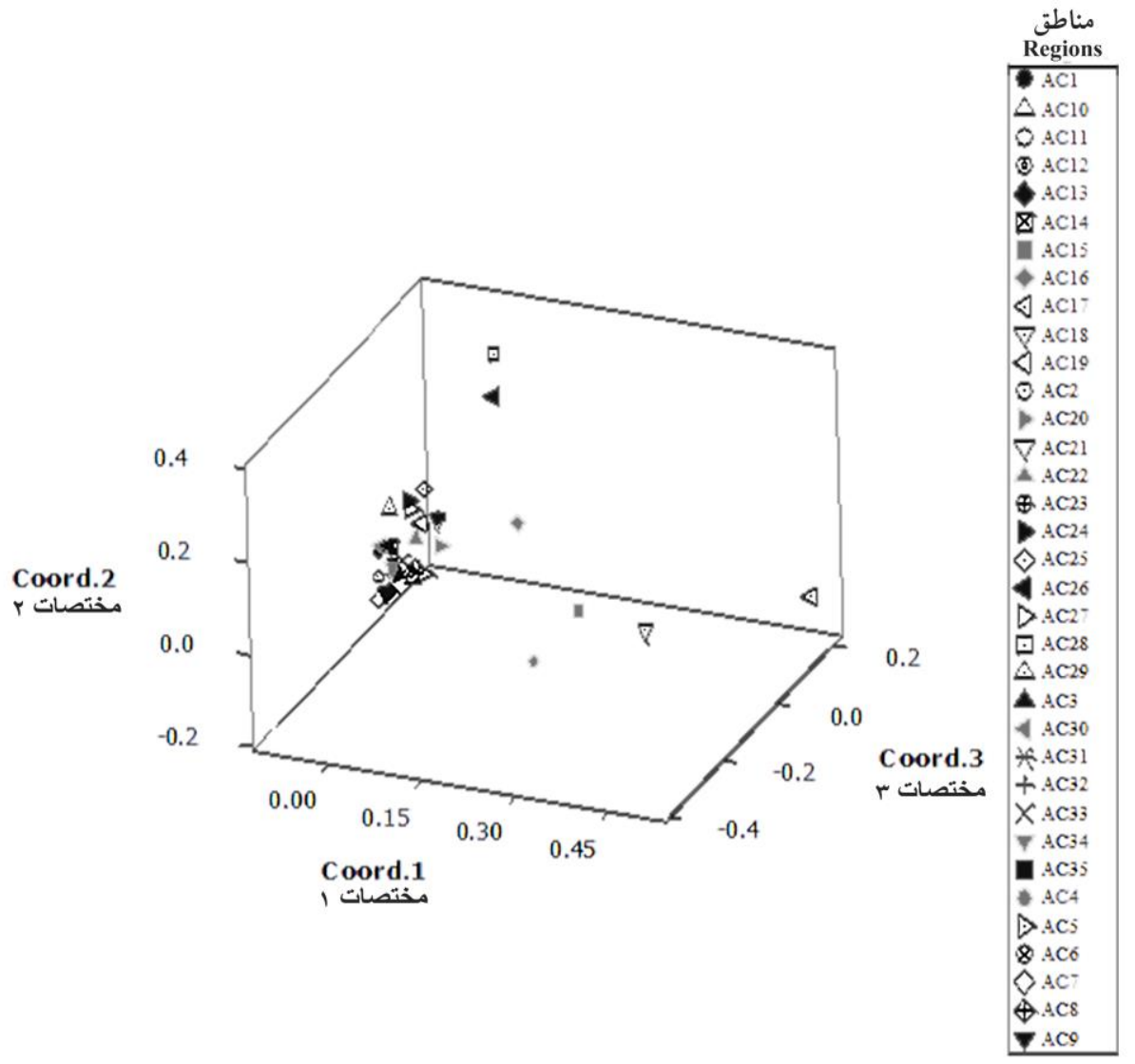

شكل r- نمودار سه بعدى حاصل از تجزيه به مختصات اصلى جمعيتهاى Ae. cylindrica بر روى سه محور مختصات اول،

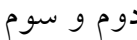

Figure 2. Three-dimensional plot based on principal coordinate analysis for Ae. cylindrica populations

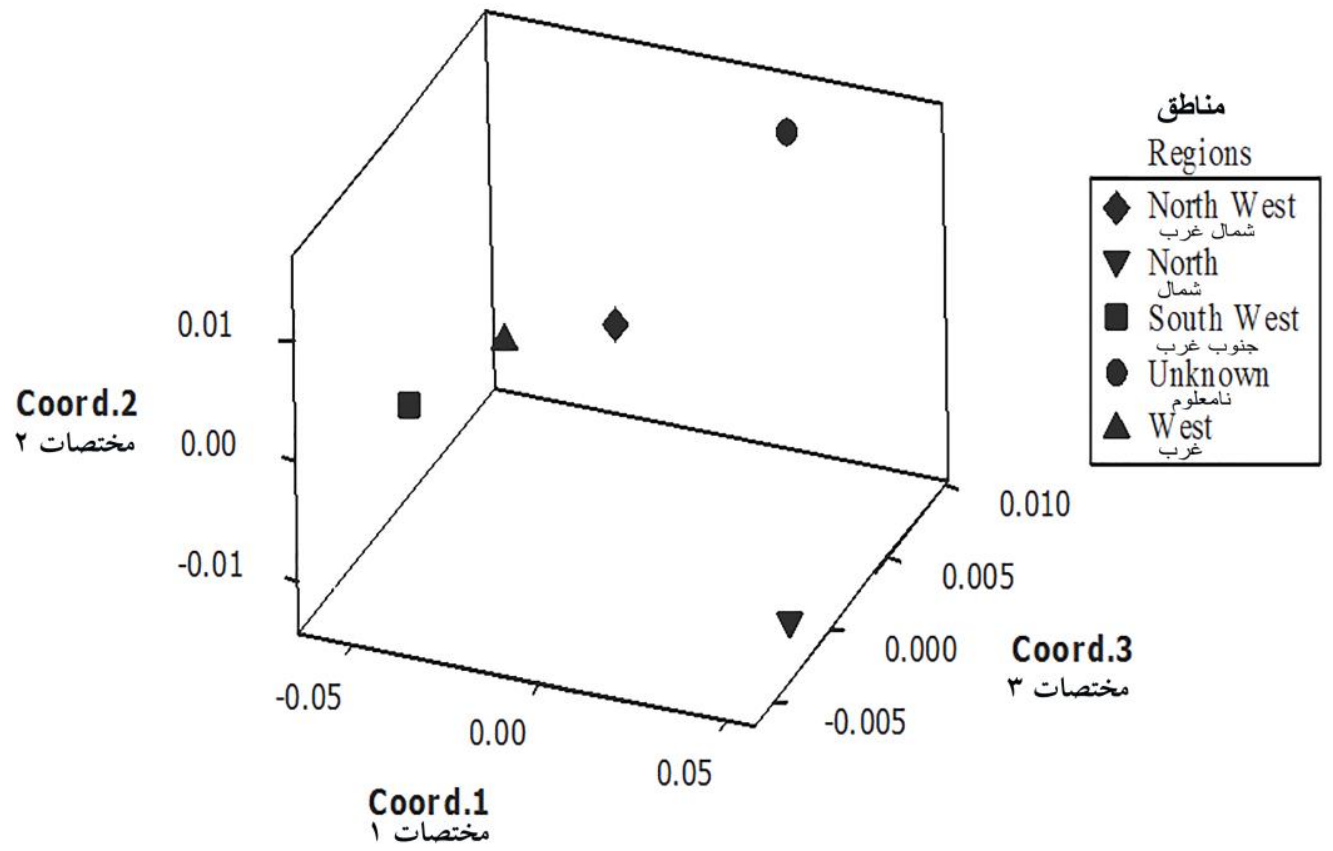

شكل r- نمودار سه بعدى ير اكنش گروههاى مختلف Ae. cylindrica بر روى سه محور مختصات اصلى اول، دوم و سوم

Figure 3. Three-dimensional scatter plot of the different groups of Ae. cylindrica 
Ae. جدولع- مقادير فاصله زنتيكى درون گروهها، فاصله زنتيكى (يايين قطر) و همسانى زنتيكى (بالاى قطر) بين گروههاى Cylindrical

Table 4. The genetic distance between groups of Ae. Cylindrica, genetic distance (above the diagonal) and genetic identity (below the diagonal)

\begin{tabular}{|c|c|c|c|c|c|c|c|}
\hline \multirow{3}{*}{ كروه } & \multirow{3}{*}{ Group } & \multirow{3}{*}{$\begin{array}{c}\text { درون گرووهها } \\
\text { Within groups }\end{array}$} & \multicolumn{5}{|c|}{ بين گروهها ( Between groups ) } \\
\hline & & & شمال & شمال غرب & جنوب غرب & غرب & ناشناخته \\
\hline & & & North & Northwest & Southwest & West & Unknown \\
\hline شمال & North & 0.16 & 粆米 & 0.93 & 0.79 & 0.88 & 0.93 \\
\hline شمال غرب & Northwest & 0.17 & 0.07 & **** & 0.86 & 0.94 & 0.97 \\
\hline جنوب غرب & Southwest & 0.61 & 0.23 & 0.15 & 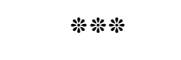 & 0.97 & 0.87 \\
\hline غرب & West & 0.34 & 0.12 & 0.06 & 0.04 & **** & 0.94 \\
\hline ناشناخته & Unknown & 0.18 & 0.07 & 0.03 & 0.15 & 0.07 & **⿻丷木大 \\
\hline
\end{tabular}

Ae. Cylindrical جدول 0- محاسبه شاخص هاى زنتيكى در گروههاى

Table 5. Estimation of genetic index among Ae. Cylindrical groups

\begin{tabular}{|c|c|c|c|c|c|}
\hline كروه & Group & $\begin{array}{c}\text { تعداد نمونه } \\
\text { No. of } \\
\text { samples }\end{array}$ & 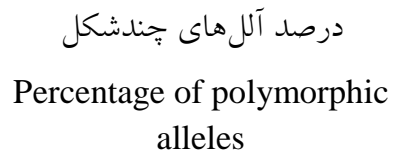 & $\begin{array}{c}\text { شاخص تصحيح شده هتروزنى } \\
\text { Modified heterogeneous } \\
\text { index }\end{array}$ & $\begin{array}{c}\text { شاخص اطلاعات شانون } \\
\text { Shannon information } \\
\text { index }\end{array}$ \\
\hline شمال & North & 2 & 16.32 & $0.090 \pm 0.015$ & $0.099 \pm 0.016$ \\
\hline شمال غرب & Northwest & 8 & 41.05 & $0.145 \pm 0.014$ & $0.205 \pm 0.020$ \\
\hline جنوب غرب & Southwest & 3 & 64.21 & $0.277 \pm 0.016$ & $0.348 \pm 0.020$ \\
\hline غرب & West & 16 & 88.42 & $0.291 \pm 0.014$ & $0.424 \pm 0.018$ \\
\hline ناشناخته & Unknown & 6 & 36.84 & $0.140 \pm 0.015$ & $0.193 \pm 0.020$ \\
\hline \multicolumn{2}{|c|}{ Total mean / ميانخين كل } & 35 & 49.37 & $0.189 \pm 0.007$ & $0.254 \pm 0.009$ \\
\hline
\end{tabular}

Ae. Cylindrical جدول 1- تجزيه واريانس مولكولى بنج گروه

Table 6. Analysis of molecular variance (AMOVA) related to 5 groups of Ae. Cylindrical

\begin{tabular}{|c|c|c|c|c|c|c|}
\hline $\begin{array}{c}\text { S.O.V. } \\
\text { S.بيع تغييرات }\end{array}$ & $\begin{array}{c}\text { درجه آزادى } \\
\text { D.f. }\end{array}$ & $\begin{array}{c}\text { مجموع مربعات } \\
\text { SS }\end{array}$ & ميانخين مربعات & $\begin{array}{l}\text { درصد واريانس } \\
\text { \% of Variance }\end{array}$ & $\begin{array}{r}\text { آماره } \\
\text { PhiPT }\end{array}$ & $\begin{array}{c}\text { درصد احتمال } \\
\text { (P_Value) }\end{array}$ \\
\hline $\begin{array}{c}\text { بين كروهها } \\
\text { Between groups }\end{array}$ & 4 & 119.27 & 29.81 & $5 \%$ & $0.045+$ & 0.09 \\
\hline $\begin{array}{c}\text { درون گرووهها } \\
\text { Within groups }\end{array}$ & 30 & 694.04 & 23.13 & $95 \%$ & & \\
\hline $\begin{array}{c}\text { جمع كل } \\
\text { Total Sum }\end{array}$ & 34 & 813.31 & & $100 \%$ & & \\
\hline
\end{tabular}




\section{References}

Anderson, J.A., Church, G.A., Autrique, J.E., Thanksley, S.D. and Sorrells, M.E. (1993). Optimizing parental selection for genetic linkage maps. Genome, 36: 181-86.

Barbara, F.R., Brian, L.J. and Jonathan, D.C. (2012). MINITAB Handbook: Update for Release 16. Web site at URL: http://www.minitab.com/en. Accessed 15 Aug 2013.

Doyle, J.J. and Doyle, J.L. (1987). A rapid DNA isolation procedure for small quantities of fresh leaf tissue. Phytochemical Bulletin, 19: 11-15.

El Bouhssini, M., Benlhabib, O., Nachit, M.N., Houari, A., Bentika, A., Nsarellah, N. and Lhaloui, S. (1998). Identification in Aegilops species of resistant sources to Hessian fly (Diptera: Cecidomyiidae) in Morocco. Genetic Resources and Crop Evolution, 45: 343-45.

Farkhari, M., Naghavi, M.R., Pyghambari, S.A. and Sabokdast, M. (2007). Genetic variation of Jointed Goatgrass (Aegilops cylindrica Host.) from Iran, using RAPD-PCR and SDS-PAGE of Seed Proteins. Pakistan Journal of Biological Sciences, 10: 2868-73.

Farooq, S., Iqbal, N., Asghar, M. and Shah, T.M. (1992). Intergeneric hybridization for wheat improvement VI. Production of salt tolerant germplasm through crossing wheat (Triticum aestivum) with Aegilops cylindrica and its significance in practical agriculture. Journal of Genetics and Plant Breeding, 46: 125-32.

Gandhi, H.T., Vales, M.I., Mallory-Smith, C.A. and Riera-Lizarazu, O. (2009). Genetic structure of Aegilops cylindrica Host in its native range and in the United States of America. Theoretical and Applied Genetics, 119: 1013-25.

Gandhi, H.T., Vales, M.I., Watson, C.J.W., Mallory-Smith, C.A., Mori, N., Rehman, M., Zemetra, R.S. and Riera-Lizarazu, O. (2005). Chloroplast and nuclear microsatellite analysis of Aegilops cylindrica. Theoretical and Applied Genetics, 111: 561-72.

Goryunova, S.V., Kochieva, E.Z., Chikida, N.N. and Pukhalskyi, V.A. (2004). Phylogenetic relationships and intraspecific variation of D-genome Aegilops $L$. as revealed by RAPD analysis. Russian Journal of Genetics, 5: 515-23.

Haji Karam, M., Naghavi, M.R., Taleii, A.R. and Aghaii, M.J. (2011). Evaluation of Genetic Diversity of Aegilops tauschii from Northern Area of Iran Using SSR Markers. Iranian Journal of Biology, 24: 390-99 (In Persian).

Iriki, N., Kawakami, A., Takata, K., Kuwabara, T. and Ban, T. (2001). Screening relatives of wheat for snow mold resistance and freezing tolerance. Euphytica, 122: 335-41.

Jaaska, V. (1981). Aspartate aminotransferase and alcohol dehydrogenase isoenzymes: intraspecific differentiation in Aegilops tauschii and the origin of the D genome polyploids in the wheat group. Plant Systematics and Evolution, 137: 259-73.

Jam-Baranduzi, A., Sofalian, O., Asghari Zakaria, R., Asghari, A. and Shokrpour, M. (2013). Assessment of genetic diversity in Aegilops species in North-West of Iran using ISSR marker. Yuzuncu Yil University Journal of Agricultural Sciences, 23: 66-75.

Johnson, B.L. 1976. Confirmation of the genome donors of Aegilops cylindrica. Nature, 216: 859-62.

Khabiri, T., Asghari-Zakaria, R., Zareh, N. and Sofalian, O. (2012). Analysis of genetic diversity based on HMW and LMW glutenin subunits in Aegilops cylindrica from Nourthwest of Iran. International Journal of Agriculture and Crop Sciences, 4: 529-33.

Khabiri, T., Asghari Zakaria, R., Zareh, N. and Sofalian, O. (2013). Assessing genetic diversity based on gliadin proteins in Aegilops cylindrica populations from Northwest of Iran. Notulae Scientia Biologicae, 5: 109-13.

Kharestani, H. (2010). Assessment of genetic diversity and genomic relationships wild and cultivated wheat species possessing a genome in different ploidy levels using SSR markers, M.Sc. Thesis, Ilam University, Iran (In Persian).

Kumar, S., Tamura, K. and Nei, M. (2004). MEGA3: Integrated software for Molecular Evolutionary Genetics Analysis and sequence alignment. Briefings in Bioinformatics, 5: 150-63. 
| بزوهشهاى زنتيك گياهى / جلد / / شماره |

Moradkhani, M., Mehrabi, A.A., Etminan, A.R. and Pour Aboughadareh, A.R. (2012). Evaluation of genetic diversity in Aegilops tauschii subspecies from Iran in compare with some wheat with D genome by using of ISSR marker. $12^{\text {th }}$ Iranian Genetics Congress, Shahid Beheshti University International Congress Center, Tehran, Iran.

Naghavi, M.R., Aghaei, M.J., Taleei, A.R., Omidi, M., Mozafari, J. and Hassani, M.E. (2009). Genetic diversity of the D-genome in T. aestivum and Aegilops species using SSR markers. Genetic Resources and Crop Evolution, 56: 499-506.

Najaphy, A., Ashrafi-Parchin, R. and Farshadfar, E. (2011). Evaluation of genetic diversity in wheat cultivars and breeding lines using Inter Simple Sequence Repeat markers. Biotechnology \& Biotechnological Equipment, 25: 2634-38.

Peakall, R. and Smouse, P.E. (2006). GenAlEx 6: genetic analysis in Excel. Population genetic software for teaching and research. Molecular Ecology Notes, 6: 288-95.

Perrier, X. and Jacquemoud-Collet, J.P. (2006). DARwin software. Web site at URL: http://darwin.cirad.fr/darwin. Accessed 10 June 2013.

Pester, T.A., Ward, S.M., Fenwick, A.L., Westra, P. and Nissen, S.J. (2003). Genetic diversity of jointed goatgrass (Aegilops cylindrica) determined with RAPD and AFLP markers. Weed Science, 51: 287-93.

Powell, W., Morgante, M., Ander, C., Hanafey, M., Vogel, J., Tingy, S. and Rafalaski, A. (1996). The comparision of RFLP, RAPD, AFLP and SSR (microsatellite) marker for germplasm analysis. Molecular Breeding, 2: 225-38.

Ranjbar, M., Naghavi, M.R., Zali, A.A., Aghaii, M.J., Pirseiedi, M. and Mardi, M. (2008). Evaluation of genetic diversity of Aegilops crassa of Iran using SSR markers. Journal of Genetic Novin, 3: 29-38 (In Persian).

Reddy, M.P., Sarla, N. and Siddiq, E.A. (2002). Inter simple sequence repeat (ISSR) polymorphism and its application in plant breeding. Euphytica, 128: 9-17.

Shiri, M. (2009). Genetic diversity assessment of Einkorn wheat populations of T.boeoticum and T.urartu from West and North-West areas of Iran using SSR markers, M.Sc. Thesis, Ferdowsi University of Mashad, Iran (In Persian).

Thomas, K.G. and Bebeli, P.J. (2010). Genetic diversity of Greek Aegilops species using different types of nuclear genome markers. Molecular Phylogenetics and Evolution, 56: 951-961.

Terzopoulos, P.J. and Bebeli, P.J. (2008). Genetic diversity analysis of Mediterranean faba bean (Vicia faba L.) with ISSR markers. Field Crops Research, 108: 39-44.

Van-Slageren, M.W. (1994). Wild Wheats: a Monograph of Aegilops L. and Amblyopyrum (jaub. and Spach) Eig (Poaceae), Agricultural University Wageningen, Netherlands.

Watanabe, N., Mastui, K. and Furuta, Y. (1994). Uniformity of the alpha-amylase isozymes of Aegilops cylindrica introduced into North American In: Comparisons with ancestral Eurasian accessions (Wang R.R.C., Jensen K.B. and Jaussi, C., Eds.) pp. 215-218, Proc $2^{\text {nd }}$ Int. Wheat Symp, Logan, UT. 


\title{
Genetic Diversity Structure of Aegilops cylindrica Accessions Revealed by Genomic ISSR Markers
}

\author{
Samira Mohammadi' ${ }^{1}$, Ali Ashraf Mehrabi ${ }^{2,}$, Ali Arminian ${ }^{2}$ and Arash Fazeli \\ 1- Former M.Sc. Student, Department of Agronomy and Plant Breeding, Faculty of \\ Agriculture, Ilam University, Ilam \\ 2- Assistant Professor, Department of Agronomy and Plant Breeding, Faculty of Agriculture, \\ Ilam University, Ilam
}

(Received: October 27, 2013 - Accepted: February 17, 2014)

\begin{abstract}
Genetic diversity among 35 accessions of Ae. cylindrica using 17 ISSR primers were investigated. Totally, 190 alleles were amplified and 188 alleles $(98.95 \%)$ o were polymorphic. Number of Amplified alleles ranged from 6 to 20 with average 11.18 alleles for each primer. Polymorphic information content (PIC) varied from 0.10 (primer UBC841) to 0.35 (primer UBC836). Marker index criterion ranged from 0.6 (primer UBC841) to 6 (primer 15). Cluster and Principal Coordinate Analysis could not completely separate accessions and showed no association between molecular diversity and geographic diversity of genotypes, indicating that there is high genetic diversity among accessions. West and south-west genotypes showed more diversity than genotypes from north and north-west of the country. Therefore, the center of diversity and origin of Aegilops cylindrica might be the western and south-western regions of country and this species might transferred from these regions to the northern parts of the country. Results of this study showed that ISSR markers are useful tools for management of genetic resources of wheat and their wild relative species.
\end{abstract}

Keywords: Aegilops cylindrica, Cluster analysis, Genetic diversity, ISSR marker, Principal coordinate analysis

\footnotetext{
* Corresponding Author, E-mail: a.mehrabi@mail.ilam.ac.ir
} 